\title{
Cart-ruts in Lanzarote (Canary Islands, Spain) volcanoes tops point to Equinoxes, Summer and Winter Solstices
}

\author{
Antonio Arnaiz-Villena ${ }^{1 *}$, Marcial Medina ${ }^{2}$, Valentín Ruiz-del-Valle ${ }^{1}$, Adrian \\ Lopez-Nares ${ }^{1}$, Julian Rodriguez-Rodriguez ${ }^{2}$, Fabio Suarez-Trujillo ${ }^{1}$ \\ ${ }^{1}$ Department of Inmunology, University Complutense, School of Medicine, Madrid, Spain \\ ${ }^{2}$ Freelance Lanzarote Archaeologists \\ ${ }^{*}$ Corresponding author: Antonio Arnaiz-Villena. Departamento de Inmunología, Facultad de Medicina, Universidad \\ Complutense, Pabellón 5, planta 4. Avd. Complutense s/n, 28040, Spain. \\ E-mail: arnaizville@hotmail.com ; aarnaiz@med.ucm.es; Web page:http://chopo.pntic.mec.es/biolmol/
}

(Received 25 April 2020; Accepted 15 May 2020; Published 6 June 2020)

\begin{abstract}
Cart-ruts have been observed in Mediterranean Basin, Eurasia and Africa. They are rock carved stripes and channels which unexpectedly converge and/or bend, not being useful for transportation use because constant parallelism is not kept. Cart-ruts came first to scholars attention in Malta and Gozo Islands where they are abundant and dated at Bronze or Temple Age of this Archipelago. A big conjoint European investment for Cart-ruts study only got a detailed inventory in several Eurasian and African countries. Age and use of Cart-ruts remains non-discovered: it is admitted that different ages and uses may not be the same for different or even same areas. Azores Archipelago Cart-ruts were left out of this study and we have recently described them at Lanzarote (Canary Islands, Spain) volcanoes tops and slopes and suggested that they could have been useful for space and time measurements. In the present study, Lanzarote is studied and Mt. Mina and Mt. Guardilama mountains Cart-ruts azimuths points to Summer and Winter Solstices sunrises respectively as measured from Quesera/"Cheeseboard" of Zonzamas, which is a prehistoric Guanche lunisolar calendar. Mt. Tenezara Cart-ruts azimuth is pointing towards Equinoxes sunrises, as observed from Zonzamas prehistoric calendar. Thus, a use for measure time and space could be a function for some Lanzarote Cart-ruts. We explain these findings in a prehistoric Guanche aborigine culture context probably common to Atlantic megalithic Bronze Age and to all Canary Islands having prehistoric inter-navigation, because all have similar rock Iberian-Guanche inscriptions and other common cultural traits. Sahara Desert abandoning by people also influenced Mediterranean and Atlantic culture. Probability that 3 out of 7 studied volcano Cart-ruts point to Solstices and Equinoxes by chance is close to zero as calculated by factorial probability methods.
\end{abstract}

Keywords: Latin, Scripts, Canary Islands, Iberian, Guanche, Lanzarote, Fuerteventura, Quesera-Cheeseboard, Pyramids, Berber, Africa, Punic, Roman, Western Sahara, Tunisia, Canaria, Calendar, Etruscan, Basque, Cart-ruts, Usko-Mediterranean, Solstice, Equinox, Zonzamas, HLA, Genetics, Sahara. Atchano, Malta 


\section{Introduction}

Cart-ruts were first described throughout Malta Archipelago; they were defined as abundant prehistoric Bronze Age Man constructions carved in rock although more recently built Cart-ruts may be possible. They consist of deep ruts, rails, tracks, grooves and channels that rarely are strictly parallel. Some of them are convergent or perpendicular to others and also they may abruptly change to curved lines. They are placed either in plains or hill slopes with a variable and high inclination (Trump 1998, 2002, 2008). Cart-ruts purpose is not known, as there were no written images, myth or verbal record about what they were used for. However, representations of Cart-ruts have recently been observed in Malta, Gozo and perhaps Fuerteventura ceramics (ArnaizVillena et al. 2019a). A conjoint multi-author European Union Project on Cart-ruts has found no new conclusion except stressing where they had been found: Malta and Turkey (Bronze Age) and also in Africa (Tunisia, Libya and Egypt) and Spain, Italy, France, Switzerland, Greece, Portugal, England and Azerbaijan (Bonnici 2007). However, this information leaves out existence of Cart-ruts in Azores Islands (Ribeiro et al. 2015, 2017; Rodrigues 2013; Rodrigues et al. 2018).

Other Cart-ruts have been described by us in Lanzarote Island volcanoes tops or slopes (Arnaiz-Villena et al. 2018, 2019a); a dating for Cart-ruts has been put forward for some of them, including Bronze Age in Malta (Trump 1998, 2002, 2008) and a prehistoric date for Lanzarote before hypothetical Roman and Phoenician culture influence since not such artifacts as Cart-ruts are known to be of either Phoenician or Roman origin: the earliest absolute ${ }^{14} \mathrm{C}$ date of human activity in Lanzarote Island was given by Atoche-Peña and Ramirez-Rodriguez $(2009$, 2016) before about 1,000 years BC. Context of genetics (Arnaiz-Villena et al. 2015, 2017), megalithic Atlantic culture Lanzarote rock calendar (“La Quesera"/Cheesboard of Zonzamas) (Medina \& ArnaizVillena et al. 2018a, 2018b), close pyramids in Occidental Sahara (Clarke and Brooks 2018) and North Africa including Morocco (Arnaiz-Villena et al. 2019b) and possibly Tenerife (Güimar and Icod de los Vinos; Sanchez-Romero at al. 2020), lead us to conclude that a prehistoric culture existed in Canary Islands cultivated by aborigine inhabitants or "Guanches". In addition, Latin rock scripts or Ibero-Guanche rock scripts described firstly throughout Lanzararote and Fuerteventura Islands have been found common to all 7 main Canary Islands (Arnaiz-Villena et al.1999, 2019b, 2019c) https://commons.wikimedia.org/wiki/File:Iberian-Guanche_inscriptions.pdf?uselang=es 
In the present paper we have measured azimuths of Cart-ruts directions on Lanzarote volcanoes tops and slopes (Figs. 1, 2), and try to find if they could measure space and/or time as it has been suggested by us (Arnaiz-Villena et al. 2019a).
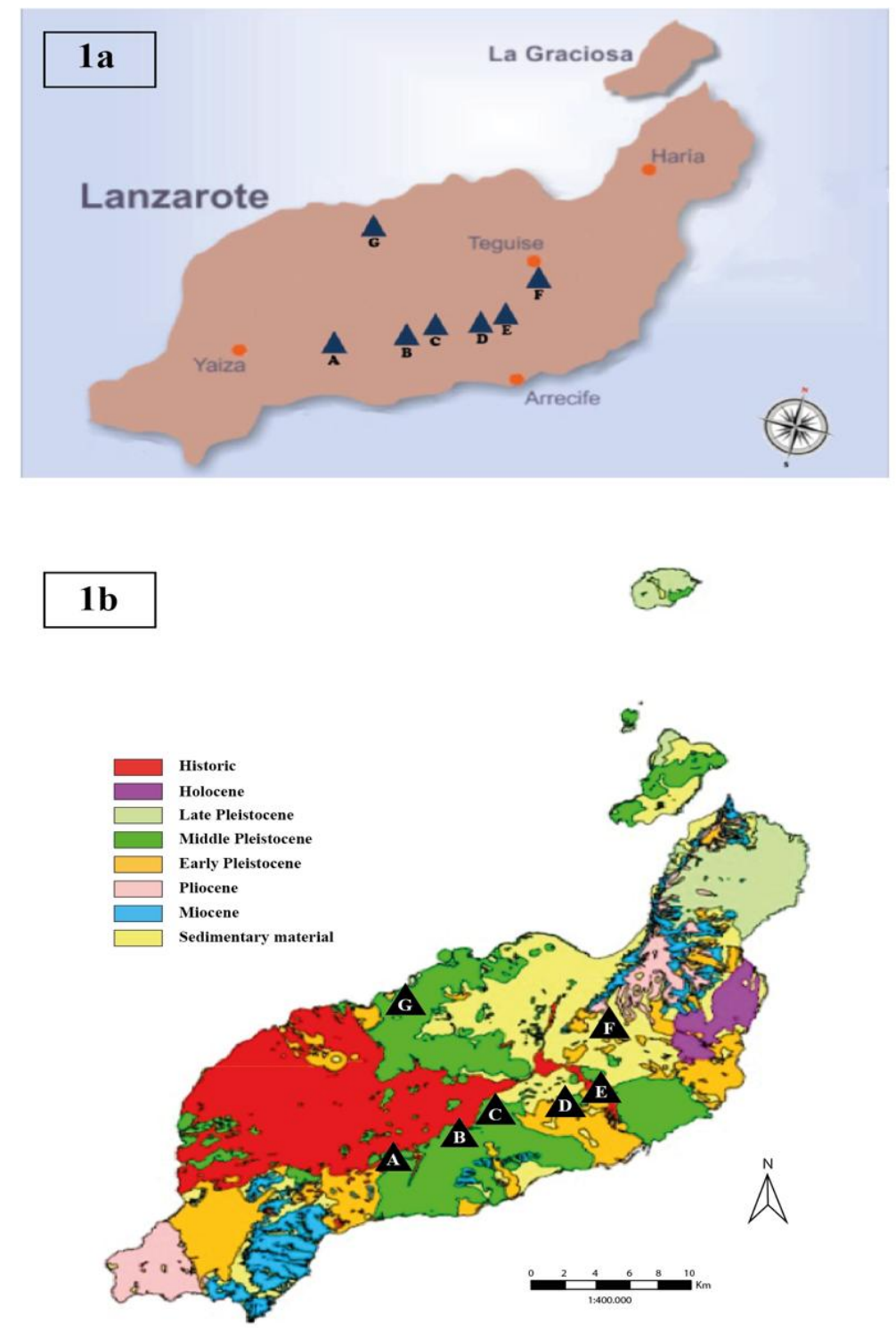

Fig. 1

\section{1a. Lanzarote Cart-ruts sites}

Cities: Yaiza: $28^{\circ} 57^{\prime} 18^{\prime \prime} \mathrm{N} 13^{\circ} 46^{\prime} 00^{\prime \prime} \mathrm{W}$, Arrecife: $28^{\circ} 57^{\prime} 45^{\prime \prime} \mathrm{N} 13^{\circ} 33^{\prime} 02^{\prime \prime} \mathrm{W}$, Teguise: $29^{\circ} 03^{\prime} 40^{\prime \prime} \mathrm{N}$ $13^{\circ} 33^{\prime} 35^{\prime \prime} \mathrm{W}$, Haría: $29^{\circ} 08^{\prime} 49^{\prime \prime} \mathrm{N} 13^{\circ} 29^{\prime} 53^{\prime \prime} \mathrm{W}$. Mountains: (A) Mt. Guardilama: $28^{\circ} 57^{\prime} 42.0^{\prime \prime} \mathrm{N}$

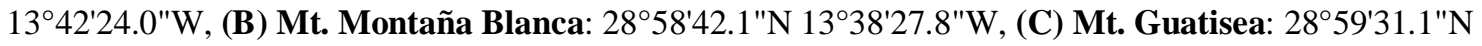

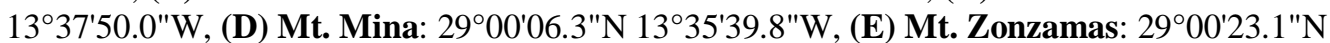

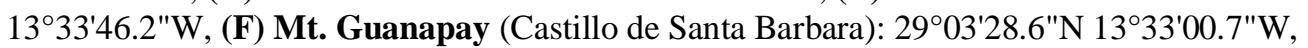
(G) Mt. Tenezara: $29^{\circ} 04^{\prime} 01.0^{\prime \prime} \mathrm{N} 13^{\circ} 42^{\prime} 24.3^{\prime \prime} \mathrm{W}$.

All formed between about 2 million years and 240.000 years ago. This map has been taken from Geoparque website: http://www.geoparquelanzarote.org/geologia/ ; https://www.idecanarias.es/resources/GEOLOGICO/LZ_LITO_unidades_geologicas.pdf 


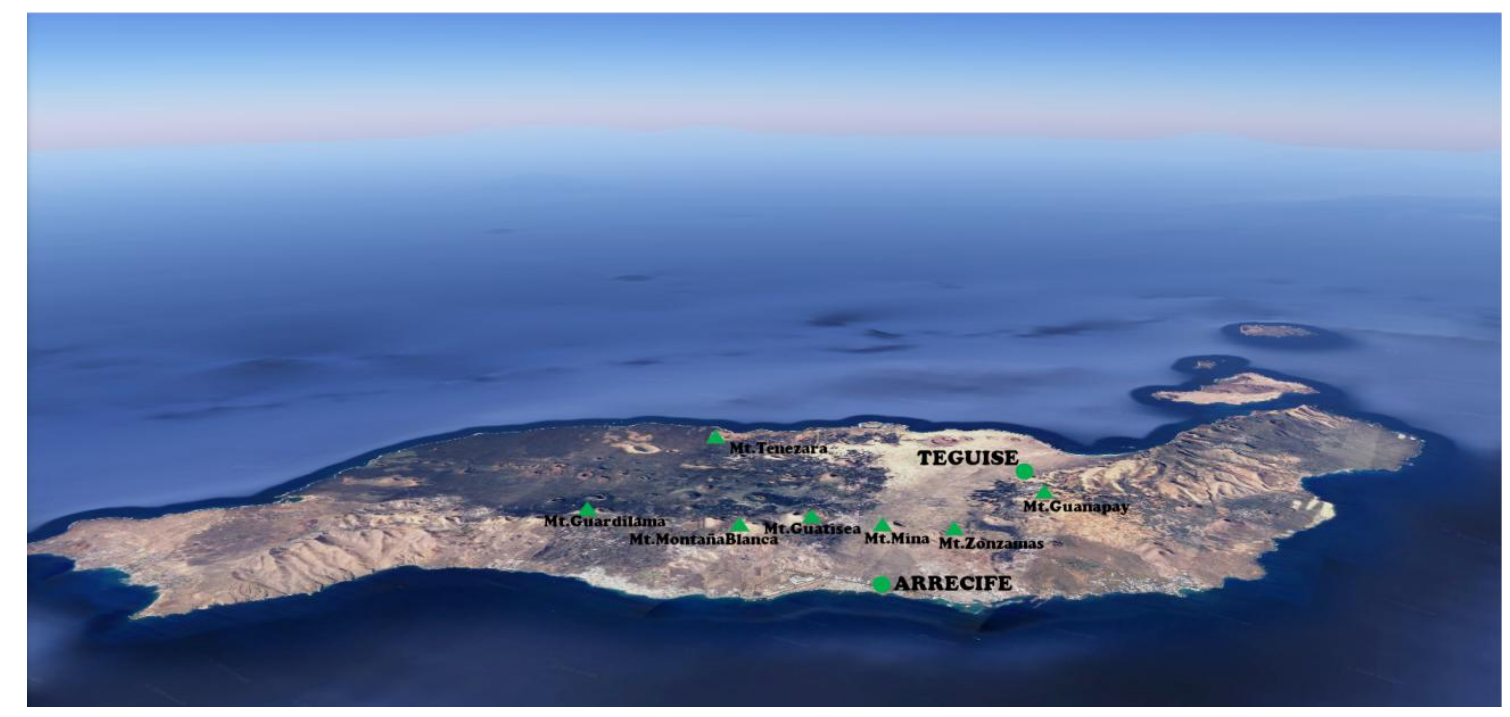

Fig. 2 Google Earth photograph placing of studied Lanzarote Island volcanoes.

\section{Material and Methods}

SPSMAP 60c color map Navigator was used for local coordinate assessment (Garmin International, Kansas, and USA). Suunto Tandem/360PC/360R DG compass and inclinometer (Turku, Finland) was used to astronomical records (Medina \& ArnaizVillena 2018a, 218b) and a computer program calculated other parameters (SunEarth Tools.com, online program). Other instruments were used for reassessing measurements: above mentioned SPSMAP navigator and binoculars 7x50 Estancos Anti-Impactos with Plastimo Compass (Sea Binoculars, Plastino USA Inc, Wilmington, Delaware, USA). Also, a Sony Camera Cybershot 14.1 Megapixels Carl-Zeiss lens Vario-Tessar was used for photograph work. In addition, Android software Ulysse Gizmo was also employed as compass/inclinometer to obtain azimuth, geographical directions and longitude/latitude. Its software was calibrated each time after one single use and several measures were taken in three different times; also reverse direction measurements were taken for assessing data. Values obtained by SAC compass/inclinometer were coincidental with those obtained by Ulysse Gizmo software in a Sony Xperia G3112 cellular phone. 


\section{Results}

Human made Cart-ruts have been observed in Lanzarote mountains: Mt. Guardilama, Mt. Montaña Blanca, Mt. Guatisea, Mt. Mina, Mt. Zonzamas, Mt. Guanapay and Mt. Tenezara (Arnaiz-Villena et al. 2019a). These mountains/volcanoes emerged in a period between about 2 million years and 240.000 years ago (Figs.1a, 1b). Thus, Cartruts may have been built up in a very ancient prehistoric period on these volcanoes: Neolithic or Preneolithic Ages, Possibly in the Megalithic Atlantic Bronze Age period, when Atlantic Dolmens of Europe (7,000 years BP, Arnaiz-Villena et al. 2013) and Africa were constructed and most Malta Cart-ruts are also thought to have been (Bronze Age) (Trump 1998, 2002, 2008).

It is striking that 3 out of 7 searched Lanzarote volcanoes show that they point out to important sunrise points: both Solstices and Equinoxes (Fig. 3).

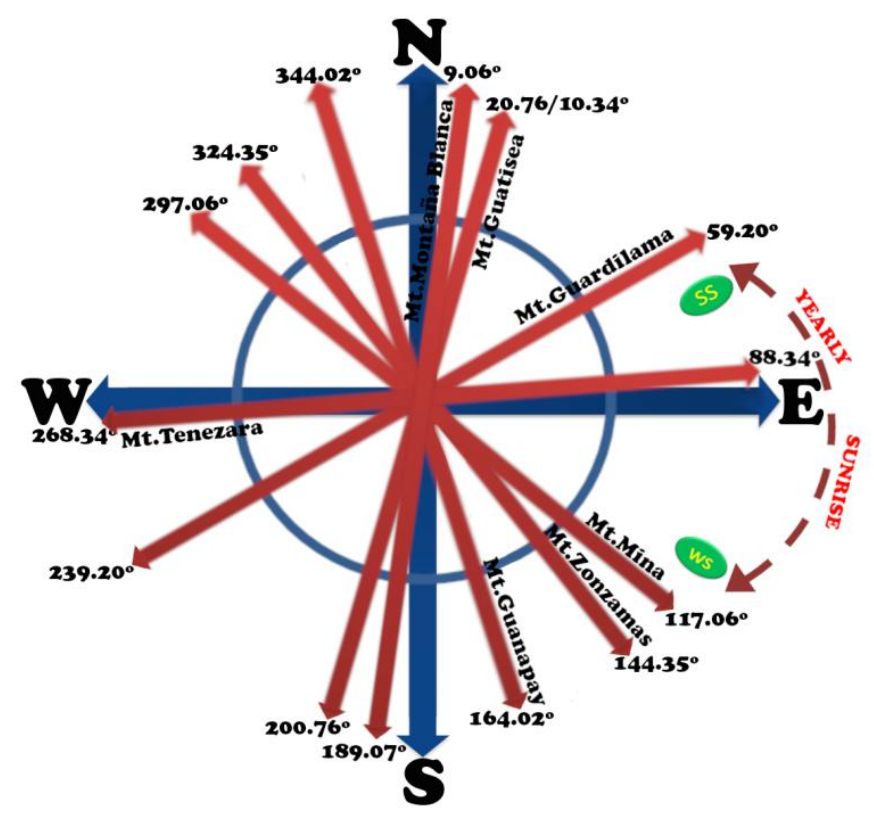

Fig. 3 Cart-ruts Azimuths pointing to Equinoxes $\left(8^{\circ}\right)$ and Solstices (Sunrises). (SS= Summer Solstice, $\left.\mathbf{6 2}^{\circ}\right)$; $\left(\mathrm{WS}=\right.$ Winter Solstice, $\left.\mathbf{1 1 7}^{\circ}\right)$.

Mt. Mina and Mt. Guardilama Cart-ruts point to Winter and Summer Solstice sunrises respectively. Mt. Tenezara Cart-ruts azimuths sunrise points to Equinoxes sunrise. Tenezara is the one studied volcano facing West. Yearly sunrises quoted in this footnote two first lines are approxinate since they have been observed from a different place Lanzarote Quesera/"Cheeseboard" prehistoric rock calendar (Medina \& Arnaiz-Villena 2018a, 2018b). 
The factorial probability that these Cart-ruts specific astronomical alignments would be due to chance is close to zero: 3 volcanoes, 360 possible Cart-ruts azimuths directions and 7 mountains examined ( $\mathrm{n}=$ non calculable, more than 40 digits number) (Figs 3,4). Thus, there is no possibility that these constructions were due to chance: they were intentional and possibly coordinated at Mt Tenazara, Mt Guardilama and Mt Mina, as some other astronomic monuments markers may have been coordinated in Gran Canaria Island (Barrios et al. 2018). Mt Montaña Blanca azimuth follows a close North/South direction with possible navigation or other implications.

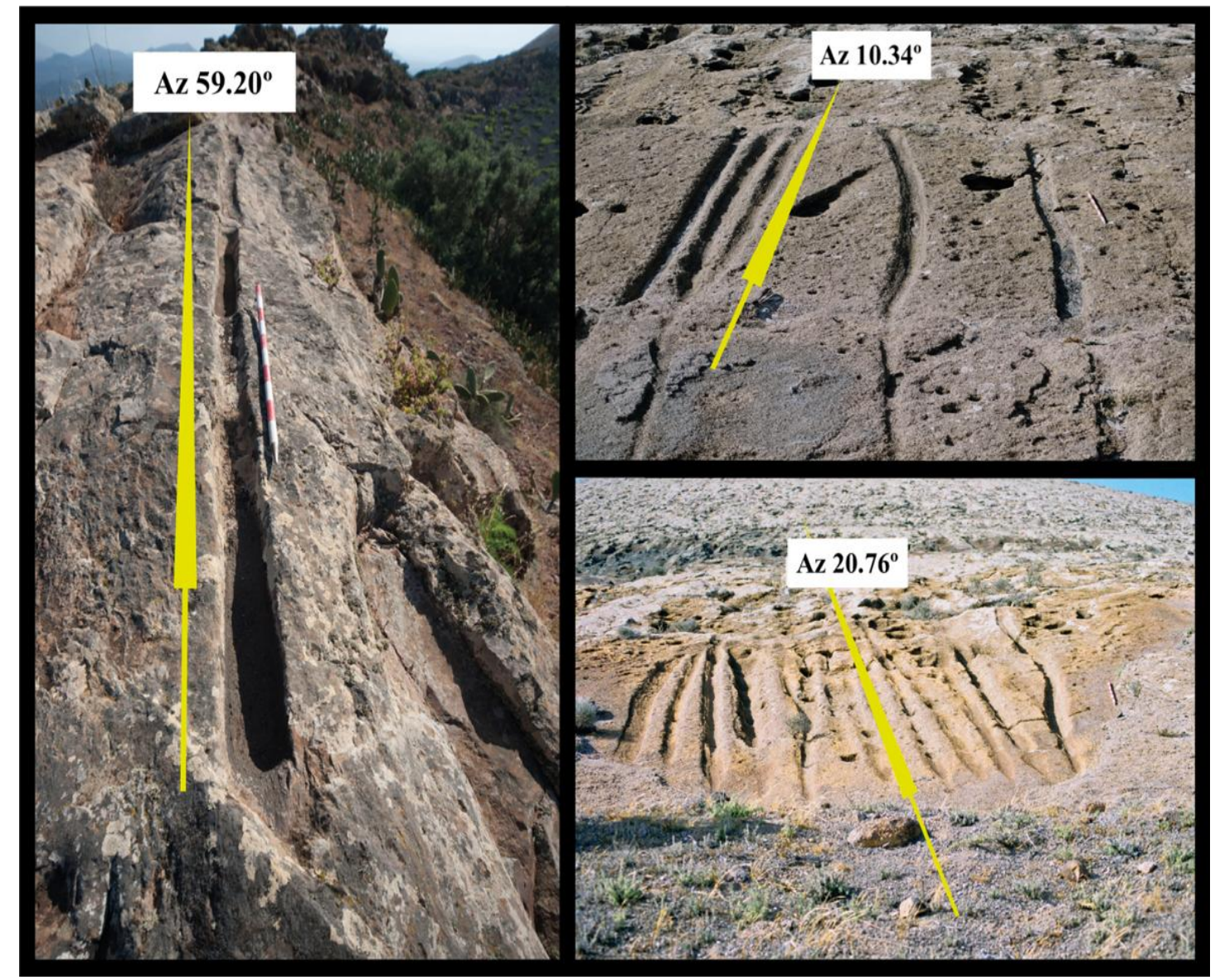

Fig. 4a. Lazarote Cart-ruts photographs and Azimuths (yellow arrows). Mt Guardilama (single one, left, A in Fig. 1) and Mt. Guatisea (both at right, $\mathbf{C}$ in Fig. 1). 


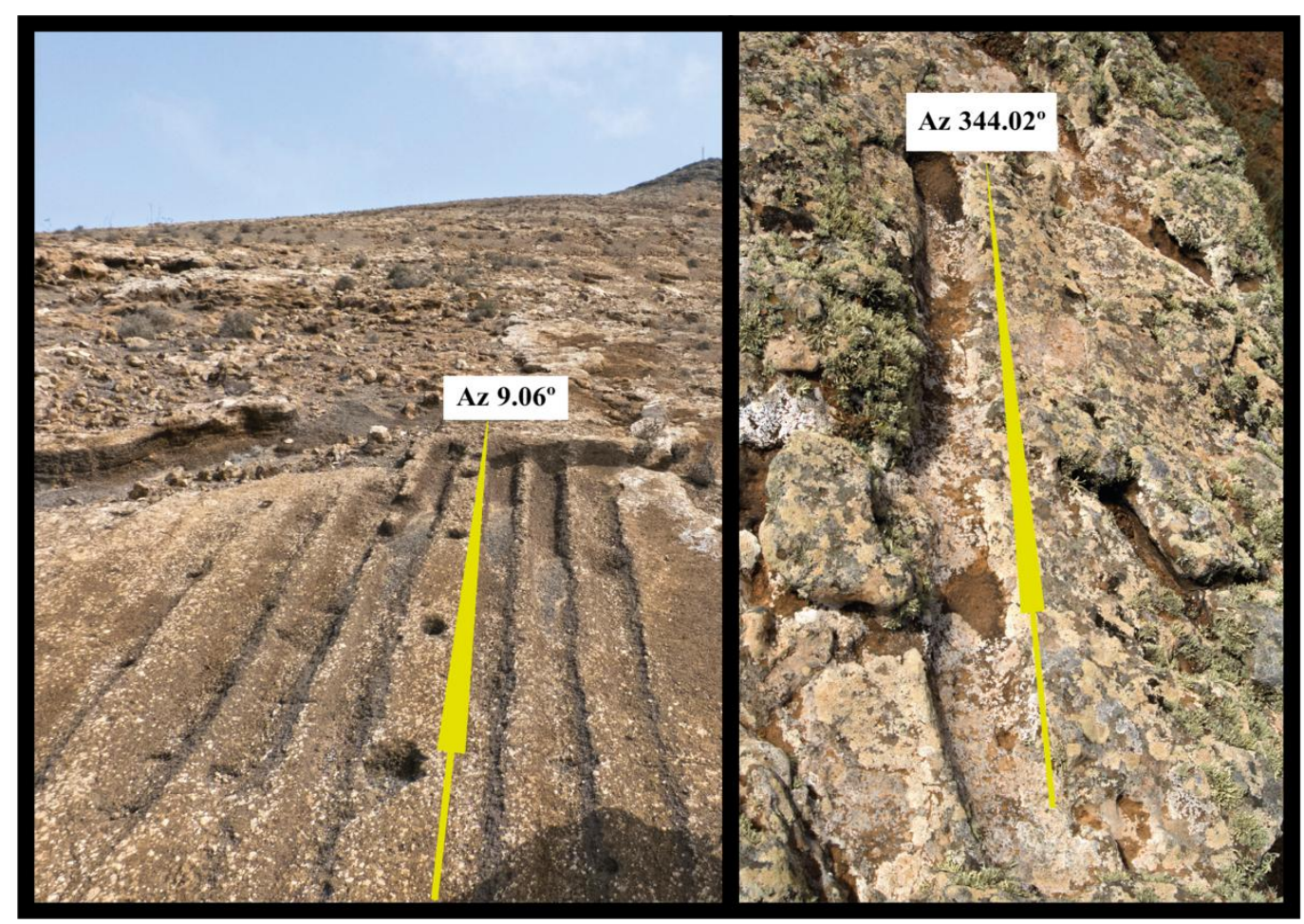

Fig 4b. Mt. Montaña Blanca (left, $B$ in Fig. 1).

A close North/South azimuth direction is observed.

Mt.Guanapay-Castillo de Santa Barbara (right, F in Fig. 1).

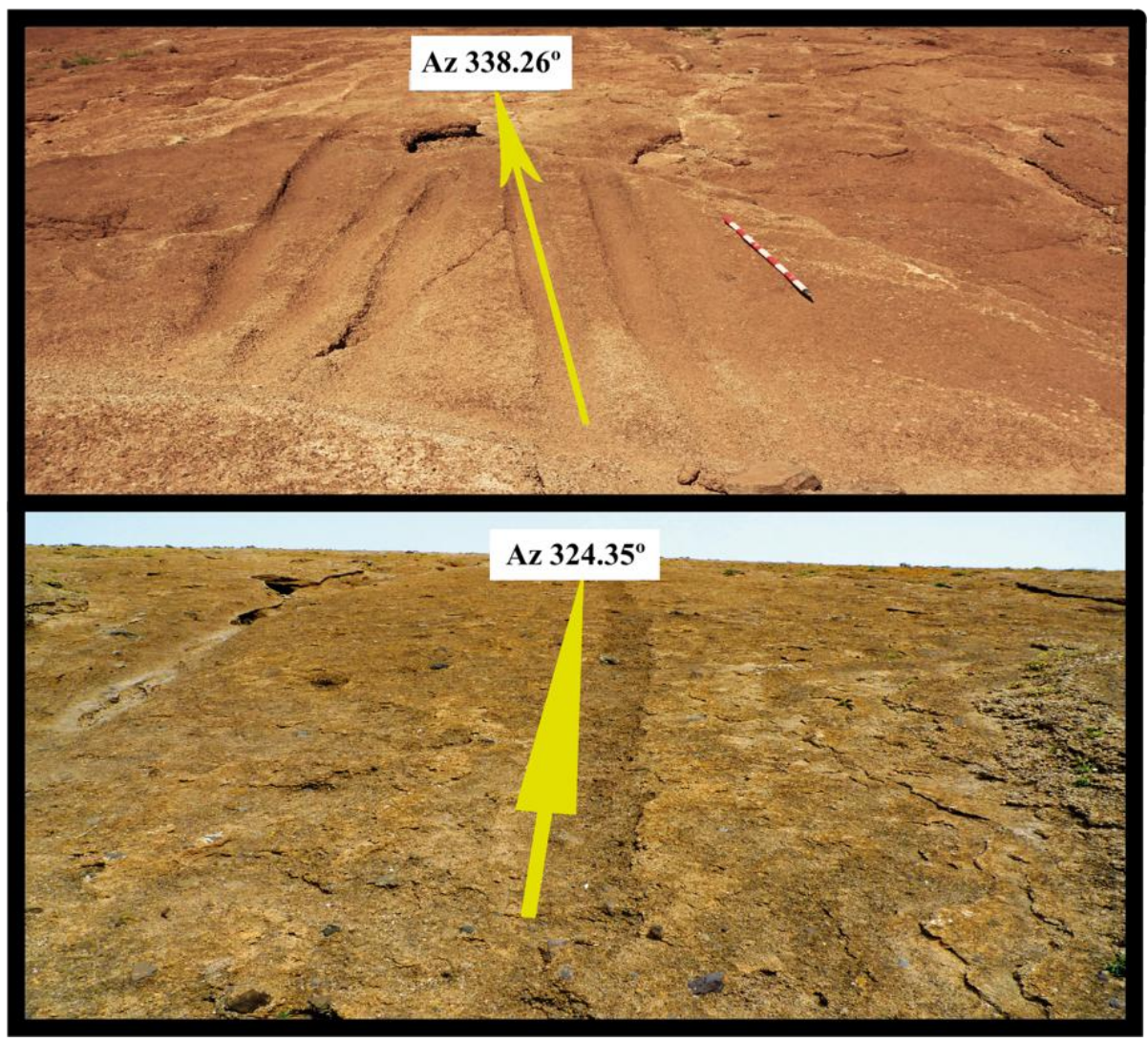

Fig 4c. Mt. Zonzamas ( $E$ in Fig. 1).

Azimuth $338.26^{\circ}$ is not represented in Fig 3 . 


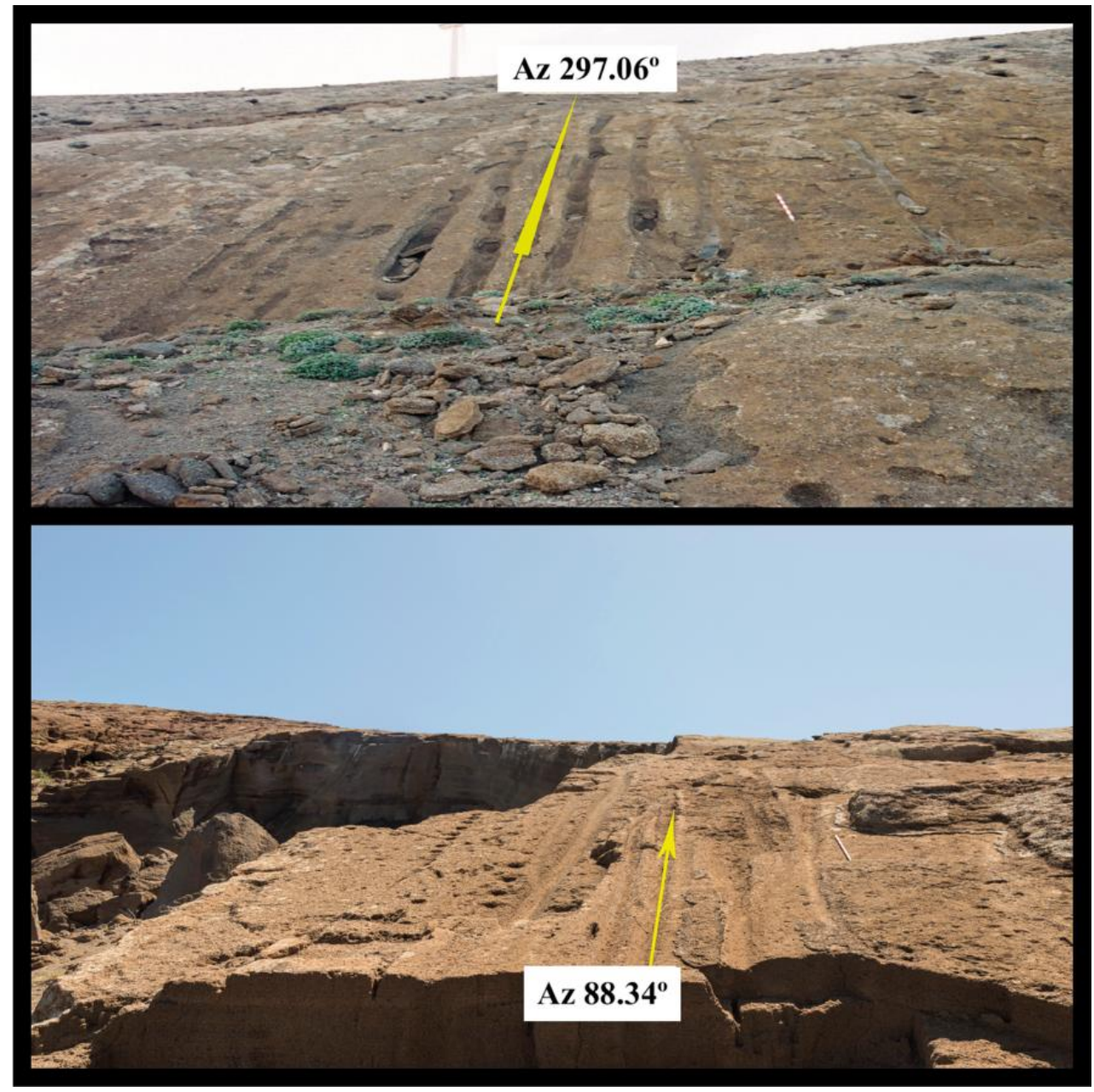

Fig. 4d. Mt. Mina (D in Fig. 1) and Mt. Tenezara (G in Fig. 1).

\section{Discussion}

Canary Islands Prehistory and Anthropology

\section{Genetics}

It was established long time ago an Africa to Iberia gene flow, probably occurred in both directions during Prehistory. These conclusions were both reached with autosomic (Arnaiz-Villena et al. 1999 from Madrid, Spain) and other genetic markers (Currat el al. 2010 from Barcelona, Spain, Bertranpetit's; Botigue et al. 2013 from Geneva, Switzerland, directed by Sanchez-Mazas). Recently, it has been confirmed by an Italian group directed by Barbujani (Gonzalez-Fortes et al. 2019). These three groups 
were long established and internationally reputed. Fregel et al. (2018), a Canarian group at La Laguna University, also found ancient genetic relationship between Africa and Europe. They also found what they call specific Canary Island haplogroups (Fregel et al. 2019): this is a poorly based conclusion, since negative results do not mean that "specific" Canarian haplogroups will not be found in other non-studied places. In addition, population genetics structure according to geography does not exist for mtDNA haplogroups; assigning individuals with a particular mtDNA haplogroup to a World region is not possible. This has been found by using a big non- ancient mtDNA database (Emery et al. 2015). In this respect, autosomal HLA and Y chromosome markers are more specific to relate and distinguish populations. Canarians cluster together with Iberian, European and African Atlantic populations (Celts/Iberians) (Arnaiz-Villena et al. 1999, 2015, 2017).

Thus, Iberian and North African gene pool is very similar (Arnaiz-Villena et al. 1999; Currat el al. 2010; Botigue et al. 2013 and Gonzalez-Fortes et al. 2019). In this context, discussing whether Canary Islands gene pool is more similar to that of North Africa or that of Iberia is useless. In fact, genetics by itself is not useful to establish relatedness between populations which must be used together with other Anthropology characters like Culture, ancient navigation, Archaeology, Language, etc (Farrujia et al. 2009). Sahara population displacement in all directions about 10,000 years BC because hyper-arid conditions occurred, probably towards southern Mediterranean Coast, Iberia and Canary Islands explaining many cultural similarities on Atlantic and Mediterranian Prehistory, including Iberian writing common to Canary Island and Iberia (ArnaizVillena et al. 2001, 2002)

\section{Rock inscriptions}

These Canarian incise linear rock inscriptions are similar to Iberian semisyllabary and another very similar ones have been found in Tunisia (Arnaiz-Villena \& Alonso-García 2001; Arnaiz-Villena et al. 2019b; Bonifay 2004). Probably, many other lineal Iberian-Guanche inscriptions have not been noticed in African archaeology sites and also may be earthed under Sahara Desert. Lineal incised rock inscriptions have also been found in western, central and eastern Europe (Runes). Some North Italian-Austrian pre-Latin "languages" have even the same signs than Ibero-Guanche scripts: Italian old scripts (Venetic, Raetic, Lepontic). 
Also Eastern Europe (https://en.wikipedia.org/wiki/Vin\%C4\%8Da_symbols Vinca inscription) has similar scripts to that of Ibero-Guanche ones dated since 5,000 years BC (and also to Iberian semi-syllabary). Other lineal incise scripts on different supports in Italy are Etruscan (Arnaiz-Villena \& Alonso-Garcia 2008) and some other scripts found in North Mediterranean, including Greece from the fifth millennium BC. Thus, all these incise lineal rock inscriptions should be taken into account to study origins, cultural and precursor role of Iberian semi-syllabary, Ibero-Guanche inscriptions and our own present day Latin alphabet. Particularly, solve which is the oldest type of lineal inscriptions and revise extensively our so called Latin alphabet origin and timing and origin of languages. In this respect, relationship with ancient Berber lineal scripts should also be studied (Hachid 2000, 2003): we proposed the "Saharian Hypothesis" for the origin of Iberians (Arnaiz-Villena el al. 1999, 2001, 2002). Finally, Ibero-Guanche rock inscriptions have been found in all seven main Canary Islands (Arnaiz-Villena et al. 2015, 2019b), which shows that a navigation and a common Guanche culture was possible among islands (Mederos-Martin \& EscribanoCobo, 2005).

\section{Lanzarote Island Cart-ruts}

They are shown with their respective azimuths in mountains depicted in Figs. 3 and 4. Figure 3 shows that Mt. Tenezara Cart-ruts azimuth is pointing to Spring and Autumn Equinoxes $\left(89^{\circ}\right)$, as they were registered at Zonzamas Quesera/“Cheeseboard” (Medina \& Arnaiz-Villena et al. 2018a, 2018b). Mt Guardilama Cart-ruts azimuth points to Summer solstice (59.20 close to $62^{\circ}$ registered at Zonzamas "Quesera") and Mt. Mina Cart-ruts point to $117.06^{\circ}$, or Winter Solstice coincidental with Winter Solstice sunrise measured form Zonzamas Quesera (Medina \& Arnaiz-Villena 2018a, 2018b). Slight variation in Equinoxes and Summer Solstice sunrise azimuths measured from Zonzamas Quesera/"Cheeseboard" and Mt. Guardilama may be due to the slight change in latitude or most likely that Cart-ruts are not accurate enough to exactly point Solstices. However, time of construction of World Cart-ruts may be variable, even for the same areas and Ecliptic obliquity may have be different slightly changing sunrise azimuths (Arnaiz-Villena et al. 2019a). 
They are made on mountains (volcanoes) tops or slopes. All mountains and Cart-ruts are facing east, i.e.: facing Moon, Sun, Canopus and Sirius stars and another stars rising at East horizon. If this Cart-ruts have something to do with star observation they are placed in the proper sites, including Mt. Tenezara which is in the West part of the Island but has a wide eastwards view since a preceding big plain permits also a clear eastwards observation: further studies with stars rising alignments are being carried out. It has independently dated Cart-ruts in Malta by using dated ceramics Cart-ruts drawings that are shown at both Victoria (Gozo) and La Valletta (Malta) Archaelogy Museums (Arnaiz-Villena et al. 2019a). Dating of some of the Cart-ruts may be assigned at Bronze or even Temple Malta Age (Bonanno 2017), if it is admitted that ceramic lines are representing Cart-ruts, as it seems. Cart-ruts at St. Georges Bay, Birzebbuga and at Mellieha Bay get into the Mediterranean Sea waters at Malta Is. Sea level must have rising at least 2 meters since construction time (Trump 2008).

Fuerteventura putative Cart-ruts are also found under water on higher tide. This would put back quite a lot these ruts building up time. Cart-ruts significance is now not solved. However, this phenomenon has not been studied in a wider context that should include Prehistory, Anthropology, Genetics, Linguistic and many other cultural traits. For instance, Tara (Telde, Gran Canaria Is.) goddess is a fat goddess (Las Palmas Museum, Gran Canaria) and many Malta goddesses statues also show fat woman (Bonnano 2017); this is also character of many European prehistoric goddesses (Gimbutas 1991). Other fat goddesses have been found at Canary Islands (Arco-Aguilar \& Navarro-Mederos 1996).

Also, Barrios has put forward (Barrios et al. 2018) that Bentrayga Equinoxes observatory at sunrise (Gran Canaria Is) was not as precise as Equinoxes calculated at Tara Cave (or Candelaria Virgin Cave, Telde). Observation of Equinoxes could be calculated at Gran Canaria Is. Tara cave for being used by all the island religious astronomical/observatory sites i.e.: also at Bentayga Almogaren. The same case could have been occurred at Lanzarote Is., where Solstices and Equinoxes could have been calculated in one particular place and then several "Queseras"/Cheeseboard or Lunisolar 
calendars may have been constructed, like that of Zonzamas found and published. At least other four "Quesera"/Cheeseboard have been documented in Lanzarote (Medina \& Arnaiz-Villena 2018a, 2018b; Arnaiz-Villena et al. 2018).

The word atxano or achano ("year" in Guanche or prehistoric Canarians language, Medina \& Arnaiz-Villena 2018a, 2018b; Arnaiz-Villena \& Alonso Garcia 2001) has been translated by us (by atx=a hill, axis, stick, ano=shade) by using Basque language, which is a remaining of Old Iberian language and also is similar to Guanche language (Arnaiz-Villena et al.1999; Arnaiz-Villena \& Alonso-Garcia 2001). This name suggests that months and seasons could be measured with a hill or stick shade projected at sunrise and/or by Sun along year across Cart-ruts. This would be a year or seasonal Sun calendar important for agriculture and other daily religious or ritual life events of Prehistoric Canarians. Other simple instruments i.e.: stick and string or rope could also be used to observe other star rising (including Moon) over horizon during night.

On the other hand, a similar Guanche coordination to that of Gran Canaria (Barrios et al. 2018) for astronomical measurements could have been carried out in Lanzarote i.e.: for measuring Equinoxes at Mt. Tenezara, and Solstices at Mt. Guardilama and Mt. Mina (Figs. 3,4), and later establish a Lunisolar calendar at Lanzarote Quesera/"Cheeseboard" like that at Zonzamas (Medina \& Arnaiz-Villena 2018a, 2018b).

\section{Acknowledgements:}

We thank University Complutense from Madrid (Spain) for its support and the following colleges who have been important for carrying out present work: Antonio Jesús Montelongo Franquiz, María Antonia Perera Betancor, Máximino Álvarez Pérez, José Manuel Espinel Cejas , Ramón Alfonso Hernández and Orlando Batista Aparicio . Marianne Van der Sluys and Jesús Gonzalez Artabe were (and are) also important for spreading light in Lanzarote archaeology and their help is indebted.

\section{Conflicts of Interest:}

authors declare no conflict of interest 


\section{References}

Arco-Aguilar C. \& Navarro-Mederos J.M. 1996. Los Aborigenes. Ed. L. Romero. La Biblioteca Canaria (Sta Cruz de Tenerife, Is. Canarias, Spain).

Arnaiz-Villena A., Martinez-Laso J., Alonso-Garcia J. 1999. Iberia: Population Genetics, Anthropology and Linguistics. Human Biology 71: 725-743.

Arnaiz-Villena A., Martínez-Laso, J., Alonso-Garcià J. 2001. The Usko-Mediterranean Languages. Human Immunology 62: 1051-1061.

Arnaiz-Villena A. \& Alonso García J. 2001. Egipcios, Bereberes, Guanches y Vascos. Ed. Visión Libros. (3rd Edition 2011) ACCI. Madrid (Spain).

Arnaiz-Villena A., Gomez-Casado E., Martinez-Laso, J. 2002. Population genetics relationships between Mediterranean populations determined by HLA allele distribution and a historic perpective. Tissue Antigens 60:111-121.

Arnaiz-Villena A. \& Alonso-Garcia J. 2008. Diccionario Etrusco-Euskera-Castellano. Ed. Vision Libros. Madrid (Spain).

Arnaiz-Villena A., Alonso-Rubio J. and Ruiz-del-Valle V. 2013. Tiwanaku (Titikaka Lake, Bolivia) and Alberite Dolmen (Southern Spain) ritual "ears". Celtic, Iberian, Aymara and Basque languages. Int. J. Mod. Anthrop 6: 61 - 76

Arnaiz-Villena A., Muñiz E., Campos C., Gómez-Casado E., Tomasi S., Martínez Quiles N., Martín-Villa M., Palacio-Gruber J. 2015. Origin of Ancient Canary Islanders (Guanches): presence of Atlantic/Iberian HLA and Y chromosome genes and Ancient Iberian language. Int. J. Mod. Anthrop 8: 67-93.

Arnaiz-Villena A., Carballo A., Juarez I., Muñiz E., Campos C., Tejedor B., MartínVilla M., Palacio-Gruber J. 2017. HLA Genes in Atlantic Celtic populations: Are Celts Iberians? Int. J. Mod. Anthrop 10: 50 - 72.

Arnaiz-Villena A., Medina M., Palacio-Gruber J., Lopez-Nares A., Ruiz-del-Valle V. 2018. Malta and Lanzarote (Canary Islands, Spain) -ruts and Rock Prehistoric Calendar at Zonzamas, Lanzarote-“Quesera"/Cheeseboard-. Int. J. Mod. Anthrop. 11: 214-231.

Arnaiz-Villena A., Medina M., Lopez-Nares A., Rodriguez-Rodriguez J., Ruiz-delValle V. 2019a. Cart-ruts in Lanzarote (Canary Islands, Spain) and Malta: first evidence of dating supported by dated ceramics. Int. J. Mod. Anthrop. 12: 115 - 140.

Arnaiz-Villena A., Lopez-Nares A., Juárez I., Ruiz-del-Valle V., Callado A., H-Sevilla A., Gomez-Casado E. 2019b. "Latín" rock scripts in Canary Islands are ancient Iberian inscriptions (Iberian-Guanche). A story of forgotten genetics, scripts, pyramids and other prehistoric artifacts.

Int. J. Mod. Anthrop. 12: $189-212$ 
Arnaiz-Villena A., Lopez-Nares A., Ruiz-del-Valle V., Juárez I., Bello A., Callado A., González JC., H-Sevilla A., Sánchez Romero G. 2019c. The Rock of the Dead: A New " Latin" or "Iberian-Guanche" Inscriptions found in Tenerife Is. (Canary Islands, Spain). Int. J. Mod. Anthrop. 2: 214- 232

Atoche Peña P. \& Ramirez Rodriguez M.A. 2009. Manifestaciones rupestres protohistoricas de Lanzarote pp. 187-209, in "Rock carvings of the European and African Atlantic Façade". BAR 2043, Archaeopress, Oxford (UK).

Atoche Peña P. \& Ramirez Rodriguez MA 2016 .c14 References and Cultural Sequence in the Protohistory of Lanzarote (Canary Islands), Iber Crono. Actas del Congreso de Cronometria para la Peninsula Iberica, pp 272-285. Barcelona (Spain)

Barrios Garcia J., Valencia Alfonso V. and Brito Mayor A. 2018. Investigaciones arqueoastronomicas en Gran Canaria. La recamara equinocial de la cueva de la virgen de la Candelaria (Tara, Telde) XXIII Coloquio de Historia Canario Americana. Las Palmas, Gran Canaria. (Islas Canarias, Spain), 1-23.

Bonifay M. 2004. Etudes sur la ceramique romaine tardive d' Afrique . BAR International Series 1301 (Oxford, UK).

Bonnano A. 2017. The Archaeology of Malta and Gozo. Heritage Malta Publishing. Ed. Gutenberg Press Ltd, Malta

Bonnici H. (Project Leader. European Union Multiauthor founded project. Culture 2000 project) 2007. The significance of Cart-Ruts in Ancient Landscapes. Ed. Midsea Books, Malta.

Botigue L R., Henn B M., Gravel S., Maples, B K., Gignoux, C. R., Corona E., Atzmon G., Burns E., Ostrer H., Flores C., Bertranpetit J., Comas D., Bustamante C D. 2013. Gene flow from North Africa contributes to differential human genetic diversity in southern Europe. Proceedings of the National Academy of Sciences 110 (29): 11791-6.

Clarke J., Brooks N. 2018. The Archaeology of Western Sahara. Oxford Books. Oxford (UK).

Currat M., Poloni E.S., Sanchez-Mazas A. 2010. Human genetic differentiation across the Strait of Gibraltar. BMC Evol. Biol. 10: 237-243.

Emery L.S., Magnaye KM., Bigham AW., Akey JM., Barmashod M.J.2015. Estimates of continental ancestry vary widely among individuals with the same mtDNA haplogroup. Am J Hum Genet 96: 183-193.

Farrujia de la Rosa A. J., Pichler W., Rodrigue A., Garcia-Marin S. 2009. Las Escrituras Libico-Bereber y Latino-Canaria en la Secuenciacion del poblamiento de las Islas Canarias. El Museo Canario. LXIV. pp. 9-50 (Gran Canaria, Spain). 
Fregel R., Mendez F.L., Bockbot Y., Martin-Socas D., Camalich-Massieu M.D., Santana J., et al. 2018. Ancient genomes from North Africa evidence prehistoric migrations to the Maghreb from both the Levant and Europe. PNAS. 26: 6774-6779.

Fregel R., Ordoñez A.C., Santana-Cabrera J., Cabrera V.C., Velasco-Vázquez J., Alberto V., et al. 2019. Mitogenomes illuminate the origin and migration patterns of the indigenous people of the Canary Islands. PLOS ONE. 14(3)

Gimbutas M. 1991. Diosas y Dioses de la Vieja Europa. 7000-3500 ac. Ediciones Itsmo. Madrid.Spain.

Gonzalez-Fortes G., Tassi E., Trucchi E., Henneberger K., Paijmans J.L.A., Diezdel.Molino D., et al. 2019. A western route of prehistoric human migration from Africa into the Iberian Peninsula. Pro Royal Soc B. DOI: 10.1098/rspb2018.2288.

Hachid M. 2000. Les premier berebers entre Mediterranee, Tassili et Nil. Edited by EDISUD. Aix-en-Provence (France).

Hachid M. 2003. Postface de L'ouvrage “Aux Origines de L'ecritureau Maroc. Corpus des Inscriptions Amarcighes des Sites D' art Rupestre du Marok" . Edited by: Skounti A., Lemdjidi A. and Nami M. Publication de L'Institute Royal de la Culture Amazighe . CEALPA, Rabat (Morocco).

Mederos-Martin A. and Escribano-Cobo G. (2005). Los aborígenes canarios y la navegación. Mayurqa. 30: 849-868.

Medina M. \& Arnaiz-Villena A. 2018a. A lunisolar prehistoric calendar in Lanzarote Island: 'LaQuesera"(Cheesboard) from Zonzamas. Int. J. Mod. Anthrop. 21:147-161

Medina M. \& Arnaiz-Villena A. 2018b. The Moon: in Prehistoric Rock Calendar "Quesera" -Cheeseboard- at Lanzarote, Canary Islands, Spain. Int. J. Mod. Anthrop. $2: 182-212$

Pichler W. 1995. Neue Ostinsel-Inschriften (latino-kanarischeInschriften) auf Fuerteventura. Almogaren 26: 21-46.

Pichler W. 2003. Las inscripciones rupestres de Fuerteventura. Ed. Calildo de Fuertevfentura, Puerta de Rosario, Fuerteventura, Canary Islands (Spain).

Ribeiro N., Joaquinito A., Rodrigues AF., Azevedo M.T. 2015. Achaeology and rock art of Macaronesia: New contributions. IV Encontro de Doutorandos e Post-Douorandos Macao.

Ribeiro N., Joaquinito A., Rodrigues AF., Azevedo MT. 2017. Arqueologia e Arte Rupestre na Macronesia, novoscontributos. Techne. 3: 113-124. 
Rodrigues F. 2013. Megalithic Discoveries in the Azores. In Proceedings of the $16^{\text {th }}$ Annual Mediterranean Studies Assoc International Congress. Angra do Heroismo (Terceira, Azores). Mediterranean Assoc.

Rodrigues F., Madruga J., Martins N. and Cardoso F. 2018. Dating the cart-ruts of Terceira Island, Azores, Portugal. Archeological Discovery, 6: 279-299.

Sanchez-Romero G., Lopez-Arencibia S. and Bello A. 2020. Una pirámide/calendario solar Guanche en el norte de Tenerife: referencias históricas, características, origen y función. Almogaren, 51: 5-55

Trump D.H. 1998. The Cart Ruts of Malta. Treasures of Malta 4(2): 33-7.

Trump D.H. 2002. Malta, prehistory and Temples. Ed. Midsea Books Ltd., Malta.

Trump D.H. 2008. Cart-Ruts and their impact on Maltese landscape. Ed. Midsea Books Ltd. Malta.

To cite this article:

Arnaiz-Villena A., Medina M., Ruiz-del-Valle V., Lopez-Nares A., Rodriguez-Rodriguez J., Suarez-

Trujillo F. 2020. Cart-Ruts in Lanzarote (Canary Islands, Spain) volcanoes tops point to Equinoxes,

Summer and Winter Solstices.

International Journal of Modern Anthropology. 2 (13): 123 - 138

DOI: http://dx.doi.org/10.4314/ijma.v2i13.4

\section{(@) $\odot \Theta \Theta$}

This article, as all articles published in this journal, is under The Creative Commons Attribution:

Attribution-NonCommercial-NoDerivatives 4.0 International (CC BY-NC-ND 4.0).

https://creativecommons.org/licenses/by-nc-nd/4.0/ 